\author{
Krzysztof Moraczewski \\ ORCID: 0000-0002-8919-2568 \\ Uniwersytet im. A. Mickiewicza w Poznaniu
}

\title{
Krytyka jako dynamika myśli humanistycznej
}

Abstrakt: Artykuł poświęcony jest rekonstrukcji idei filozoficznej krytyki kultury. Nacisk położono na ustanowienie krytyki poprzez odróżnienie doksa i episteme i jej rozwinięcie w postaci greckiej krytyki mitu. W następnej kolejności rozważane jest rozszerzenie krytyki na warunki możliwości poznania w filozofii kantowskiej i jego konsekwencje dla statusu rozumu jako instancji krytyki. Prowadzi to do frankfurckiej koncepcji instrumentalizacji rozumu, której omówienie stanowi punkt wyjścia próby określenia współczesnego statusu krytyki kultury.

Słowa-klucze: kultura, krytyka, rozum, wiedza

\section{Ustanowienie krytyki}

Wyrażenia takie jak „krytyczna teoria kultury” lub „humanistyka krytyczna" można by właściwie traktować jako pleonazmy. Ustanowienie refleksji nad kulturą — powiedzmy lepiej: refleksji nad przygodnością ludzkich przekonan, która to refleksja pojawia się na dwa tysiąclecia przed upowszechnieniem się terminu „kultura” w jego wykładniach filozoficznych i antropologicznych jest bowiem zarazem ustanowieniem wiedzy krytycznej i refleksja ta rodzi się jako „krytyka kultury”. W stwierdzeniu takim jedynie termin, a nie pojęcie jest anachronizmem. Krytyka ta bierze swój początek z greckiego zwątpienia w mit, z odkrycia, że opowieść o nienaruszalnej dotąd prawdzie może być „bajaniem poetów", że można poszukiwać jej genezy, odróżniać rdzeń mitu od jego fałszywych modyfikacji, odrzucać jego sens dosłowny, wyposażając zarazem mit w akceptowalny dla krytycznego namysłu sens alegoryczny. W przemianie tej uczestniczy całość greckiej filozofii bez względu na jej odcienie, może z wyjątkiem mądrościowych maksym tak zwanych siedmiu mędrców, które mimo ich historycznej roli więcej wydają się mieć wspólnego z księgami mądrościowymi Biblii niż z przełomem, jaki przyniosła jońska filozofia przyrody — zatem 
wszystkie greckie szkoły filozoficzne: jończycy, poprzez poszukiwanie arché, która jest zasadą bardziej pierwotną niż początek opisany przez mit; eleaci z ich koncepcją niezmiennego bytu, którego nie poświadcza żaden przekaz mityczny; sofiści z ich uświadomieniem sobie przygodności i instrumentalności ludzkich przekonań; sokratycy z ich podejrzeniem, że cnota i prawda mogą być czymś innym, niż powszechnie się mniema; Platon z jego wolnością konstruowania pseudomitu jako filozoficznej alegorii; Arystoteles, świadom historycznego procesu ustanawiania wiedzy; neoplatonicy z przekształcaniem mitu z etiologicznej opowieści o początkach w system metafizycznych alegorii. Zasadnicze odkrycie jest wspólne i można je wyrazić jako twierdzenie, że zastany świat greckich przekonań, to, co nazywamy dzisiaj grecką kulturą, może być jedynie światem przygodnych mniemań, któremu nie przynależy walor prawdziwości. W tym sensie filozofowie są najmniej reprezentatywnymi przedstawicielami starożytnej greckiej wspólnoty, stanowią rodzaj greckiej kontrkultury: zastanej kulturze greckiej, w którą zwątpili, przeciwstawiają efekt krytycznego nad nią namysłu. Mają też przeciwstawienie pojęciowe, które cały ów proces dobitnie wyraża. Zadaniem filozofii, przynajmniej w najszerzej rozumianej tradycji sokratejskiej, jest przegląd i krytyka doksa, przygodnych i przypadkowych mniemań tworzących powszechnie akceptowany obraz świata na mocy bezwładności tradycji, a przyjmowanych bez - z filozoficznego punktu widzenia — dostatecznej racji. Ów przegląd i krytyka doksa ustanawia episteme, a więc wiedzę, która przekracza wymiar przygodności, dla której istnieje dostateczna racja, wytrzymuje krytyczny namysł. „Racja dostateczna”, „krytyczny namysł” itp. to wszystko terminy, które do greckiego początku można odnieść jedynie anachronicznie, ale jest to anachronizm niezbędny, albowiem ustanawia on łączność między greckim odróżnieniem doksa i episteme a wszelkimi późniejszymi jego przekształceniami: zasadą poszukiwania racji dostatecznej, zasadami krytyki filozoficznej u Christiana Wolffa, ideą krytyki transcendentalnej u Immanuela Kanta, krytyką ideologii u Karola Marksa, krytyczną teorią społeczeństwa u Maxa Horkheimera i „zasadą” dekonstrukcji u Jacquesa Derridy. Jeśli filozoficzne zwątpienie jest przede wszystkim zwątpieniem w mit, to kluczowym jego rozszerzeniem okazuje się filologia renesansowych humanistów. Lorenzo Valla (około 1406-1457), dokonując krytyki autentyczności tak zwanej darowizny Konstantyna i tworząc w ten sposób fundamentalne narzędzia wszelkiej krytyki filologicznej i krytyki źródeł historycznych w ogóle, objął tymi samymi wątpliwościami już nie tylko mit i zdroworozsądkową wiedzę o świecie, ale wszelki wytworzony przez człowieka przekaz, o którym nigdy nie wiadomo trzech rzeczy: czy mówi prawdę, czy może mówić prawdę i czy chce mówić prawdę.

Nie sposób próbować przedstawiać tutaj meandrów tego procesu, ale na nasze potrzeby trzeba wyróżnić kilka jego kluczowych etapów. Po pierwsze, zapoczątkowaną przez greckich filozofów krytykę mitu w wąskim etnologicznym rozumieniu, to jest etiologicznego i legitymizującego przekazu tradycyjnego, 
powiązanego z siecią praktyk rytualnych i charakteryzującego się wewnętrzną konstrukcją pojęciową, opisywaną przez Claude’a Lévi-Straussa jako „mito-logika”. Kluczowy dla przyszłości myśli krytycznej był w tym zakresie nie zestaw szczegółowych rozstrzygnięć, lecz przeciwstawienie mito-logice logiki innego rodzaju, która swój najdoskonalszy wyraz znalazła w Organonie Arystotelesa. Ze względu na uniwersalny charakter etiologiczny mitu, wyjaśniającego całość kosmosu, jego krytyka wymagała ustanowienia dwojakiej metody, hermeneutycznej i doświadczalnej zarazem, znajdującej swoje spełnienie z jednej strony w neoplatonizmie Jamblicha (ok. 250-326) i Proklosa (412-485), z drugiej zaś w przyrodniczych i matematycznych, w tym zwłaszcza astronomicznych i anatomicznych, poszukiwaniach uczonych aleksandryjskich i sycylijskich, głównie okresu hellenistycznego. Nowożytne ustanowienie nauki, które można śledzić od Galileusza po Isaaca Newtona, da się interpretować jako rekonstytucja doświadczalnego skrzydła greckiej krytyki mitu, taka jednak, która prowadzi do stopniowego zerwania łączności z wymiarem hermeneutycznym tejże krytyki, co zostanie przypieczętowane metodologicznie poprzez przeciwstawienie $\mathrm{Na}$ turwissenschaften i Geisteswissenschaften. Po drugie, wyróżnimy na nasz użytek przeniesienie ostrza krytyki z zastanego zespołu przekonań, czyli wszelkiego doksa, a nie tylko już mitu w ścisłym rozumieniu, na sam proces poznawczy i naturę poznania. Jest to etap znajdujący swe spełnienie w tradycji wiodącej od angielskiego oświecenia z Davidem Hume'em na czele do Kanta i Krytyki czystego rozumu jako rozbioru krytycznego samej instancji krytyki. Po trzecie, etap obejmujący, jak sądzę, także naszą współczesność wyraża się w krytyce nakierowanej na warunki poznania uprzednie względem samego aktu poznania, jednak nie w sensie transcendentalnym, jak u Kanta, lecz społeczno-kulturowym: historyczność (od Georga W.F. Hegla począwszy), determinacja przez język (od Wilhelma von Humboldta po Derridę), stosunki władzy (od szkoły frankfurckiej po Michela Foucaulta), stosunki klasowe i ekonomiczne (od Karola Marksa po Pierre'a Bourdieu), stosunki płci (od Johanna J. Bachofena po Judith Butler) itp. Nie jest to oczywiście żaden opis historyczny, uproszczenia są karkołomne, a pominięcia karygodne. Chodzi tylko o unaocznienie jednej rzeczy, a mianowicie procesu, w którym krytyka się poszerza, przechodząc od wiedzy zastanej do podstaw możliwości wiedzy i jej miejsca w społecznej całości, a więc ten właśnie proces, który Theodor W. Adorno i Max Horkheimer nazwali „oświeceniem”. Proponowana przez nich definicja oświecenia jako rozszerzającego się procesu demityzacji jest w pełni możliwa do przyjęcia, jeśli zrezygnować ze ścisłego etnologicznego rozumienia mitu i przejść do jego koncepcji poszerzonej, przyjmowanej na przykład przez Leszka Kołakowskiego czy Odo Marquarda. Humanistyka jako całość została ustanowiona w trakcie tego procesu, teoria kultury zaś jest jednym z jego efektów. Powtórzmy więc raz jeszcze: krytyczna teoria kultury i humanistyka krytyczna to pleonazmy. 
Proces oświecenia jest nie tylko procesem poszerzonej demityzacji, lecz także procesem nieustannego ustanawiania instancji krytycznej. Kto bowiem prowadzi krytykę, skąd czerpie jej podstawę, jak wychodzi się poza doksa i wreszcie jakie uzasadnienie mają wartości, $\mathrm{w}$ tym wartości poznawcze, po zwątpieniu w powszechnie przyjmowane przekonania? Grecka odpowiedź ukonstytuowała ciąg rozstrzygnięć, w którym wciąż jeszcze tkwimy. Ową odpowiedzią było ustanowienie logosu jako przeciwieństwa mythos, logosu, który nie jest przecież dla Greków zespołem procedur poznawczych, lecz formą istnienia, prazasadą, rzeczywistością właściwą. Ustanowienie logosu oznaczało zatem konieczność budowy kontrintuicyjnej ontologii. Logos przynależy do sfery bytu rzeczywistego w odróżnieniu od tego, co się ledwie jawi — krytyka mitu staje się krytyką samej konstytucji rzeczywistości. Tak to wygląda przynajmniej w tradycji pitagorejskiej, eleackiej i platońskiej. W tradycji greckiej zatem krytyka wydaje się tak mocno ufundowana ontologicznie, że może sobie rościć pretensje do przekroczenia granic doksa, do zewnętrznego punktu widzenia. Wydaje się, gdyż myśl grecka ma pod tym względem nieczyste sumienie, nie potrafi bowiem odpowiedzieć na pytanie, które zarysowuje się jasno u sofistów i sceptyków: czy logos nie jest tylko retorycznym skutkiem operacji językowych, inną przygodnością greckiego świata, przesunięciem wewnątrz doksa, które ustanawia nowe mniemania na miejsce mniemań tradycyjnych, nie zbliżając się do statusu episteme. Taki jest sens Pyrrońskiej rozprawy z grecką tradycją filozoficzną: wszystko jest doksa, nie można wyjść poza koło ustanawiania konkurencyjnych mniemań, nie można nic wiedzieć, można jedynie mniemać. Oznacza to, że ontologiczne ufundowanie logosu jest nadspodziewanie chybotliwe i problematyczne już u swego zarania i — by tak powiedzieć - w Grecji zaistniały już filozoficznie wszystkie późniejsze etapy dialektyki oświecenia, które potrzebowały jeszcze dwóch tysięcy lat, aby się historycznie rozwinąć. Stąd może tak łatwy mariaż greckiej filozofii z chrześcijaństwem.

Wiele napisano o tym, co grecka filozofia mogła zaoferować chrześcijaństwu, ale chrześcijaństwo miało dla greckiej filozofii dar jeszcze cenniejszy. Wprowadzając bowiem koncepcję bytu nieuwarunkowanego, który sam jest źródłem wszelkiej prawomocności, utożsamiając ów byt z logosem i wreszcie uznając logikę za formę Bożego umysłu, chrześcijaństwo ugruntowało myślenie filozoficzne w czymś odeń pewniejszym i odsunęło pretensje pyrronizmu. „Wiara szuka zrozumienia" to nie formuła obskurantyzmu, lecz formuła nowego ufundowania logosu, którego nie można naruszyć, gdyż konsekwencje takiego naruszenia ukazali już sofiści i sceptycy. Sytuacja staje się paradoksalna, gdyż myśl filozoficzna może istnieć tylko jako myśl krytyczna - przynajmniej w tradycji ufundowanej przez Greków - a zarazem nie wolno objąć krytyką podstaw jej własnej pra- 
womocności. Rozszerzenie tej krytyki tak, by objęła podstawę prawomocności samego rozumu, jakie dokonało się w myśli francuskiego i angielskiego oświecenia, oznaczało zatem kluczowy zwrot. Nie sposób jednak przecenić zwłaszcza rewolucji kantowskiej, nie tylko w tym znanym jej wymiarze, w którym przenosi ona zasady konstrukcji doświadczenia z jego zewnętrznych źródeł na strukturę władz poznawczych podmiotu, lecz także, a może przede wszystkim, przez ustanowienie autokrytyki samej instancji krytycznej.

Rozum w Kantowskich Krytykach kieruje swój namysł przede wszystkim ku samemu sobie, dokonując badania i rewizji własnych roszczeń, ale też zajmuje miejsce prazasady. Inaczej niż w myśli scholastycznej — przemianę tę zainicjowały już Medytacje nad pierwsza filozofia Kartezjusza — rozum nie ma już wspierającej go, samoustanawiającej się zasady, bytu nieuwarunkowanego jako swego źródła, ale na odwrót, sam musi ów byt nieuwarunkowany ustanowić. Jako rozum czysty okazuje się jednak do tego niezdolny, a wszelkie próby rozumowego ustanowienia bytu nieuwarunkowanego rozpływają się w antynomiach. Byt nieuwarunkowany, absolut leży poza zasięgiem prawomocnego użycia rozumu, w sferze, w której mowa owego rozumu staje się pusta i wewnętrznie sprzeczna - nie na mocy błędu, ale na mocy samej natury racjonalnego myślenia. Dopiero rozum praktyczny jest w stanie przełamać ten krąg niemocy myślenia, ale w sposób okrężny i nierozstrzygający. Byt nieuwarunkowany i inne odziedziczone po chrześcijaństwie koncepcje nie uzasadniają moralności, która jeśli ma zachować walor powszechności, nie może mieć źródła innego niż pusta rozumowa forma prawa, lecz są jedynie tej moralności postulatami. Rozum praktyczny postuluje tylko istnienie Boga i nieśmiertelnej duszy człowieka jako takie idee, które zdają się wynikać z konstrukcji moralności. Postulat ten nie ma rangi dowodu. To odwrócenie tradycyjnego stosunku między Bogiem a rozumem, zamiana miejsc między fundującym a fundowanym, rozwijane jest przez Kanta zarówno w Krytyce praktycznego rozumu, jak i w Uzasadnieniu metafizyki moralności.

Jeszcze jedna istotna przemiana dokonuje się w Kantowskich Krytykach. Samemu stając się fundującym źródłem, rozum przestaje być tylko poznawczy, staje się także aksjologiczny, przejmując także tę funkcję źródła, jaką jest ustanawianie wartości. Imperatyw kategoryczny nie jest oczywiście wartością per se, gdyż przynajmniej w swym pierwszym sformułowaniu, sławnym „postępuj zawsze tak, aby maksyma twojego postępowania mogła być prawem powszechnym", ma charakter pustej treściowo zasady formalnej. Nie będąc zatem samemu wartością, imperatyw stanowi jednak probierz wartości, narzędzie krytyki aksjologicznej, pozwalające na zważenie wartości samych wartości. Poddane owemu probierzowi rzeczywiście istniejące systemy wartości utrzymają się lub nie, przez co moralność jako taka nabiera charakteru czegoś ustanowionego przez rozum. Ta rozbieżność między etyczną słusznością a empiryczną moralnością przygotowana została już przez Kartezjusza i Hume’a na płaszczyźnie logicznej (wrócimy do tego za chwilę) i wyrażona najpełniej w postaci zasady przeciwieństwa po- 
winności i bytu. Umieszczony wewnątrz dialektyki powinności i bytu imperatyw kategoryczny staje się jedynym źródłem wartości, prazasadą powinności, której jedynie przynależy etyczna słuszność, jakiej pozbawiony jest byt, czyli przygodne moralności rzeczywistych społeczeństw. Owo przejście od pustej formy prawa do formy aksjologicznej aktywności rozumu widoczne jest już w drugim sformułowaniu imperatywu, pochodzącym przecież od samego Kanta: „Postępuj tak, byś człowieczeństwa tak w twej osobie, jak też w osobie każdego innego używał zawsze zarazem jako celu, nigdy tylko jako środka"1.

Filozofia krytyczna Kanta była swoistym punktem szczęśliwym, Edenem myśli krytycznej w ogóle: oto instancja krytyki, rozum, gruntuje sam siebie jako źródło poznania i źródło wartości etycznych i estetycznych. Jako rozum czysty, rozum praktyczny i władza sądzenia dokonuje przeglądu samego siebie, wytycza granice własnej prawomocności i staje się w swym myśleniu krytycznym w pełni autonomiczny i samowystarczalny. Oddziaływanie tego punktu jest w praktykach naszych społeczeństw widoczne do dziś, począwszy od zachodniej wiary w uniwersalną wartość praw człowieka, jako tego przygodnego tworu przypadkowej kultury, który wytrzymuje krytyczne spojrzenie rozumu i jest w ten sposób na nowo ukonstytuowany w charakterze wartości uniwersalnej. Można pojąć owo pośmiertne trwanie Kantowskiej wiary w autonomiczny rozum, gdyż wiara ta stanowi mocną podstawę działania, w przeciwieństwie do paraliżujących skutków dalej posuniętej krytyki.

Krytyka jednak została posunięta dalej. Już Friedrich W.J. Schelling miał problem: jak pogodzić pozahistoryczny charakter rozumu z rzeczywistością historii? Koncepcja potencjalności absolutu, a więc twierdzenie, że rzeczywista historia jest zmienna dlatego, że nigdy nie prezentuje absolutu w całości, lecz zawsze tylko jedną z jego wielu potencjalności - teza fundamentalna zwłaszcza dla w Schellingowskiej Filozofii sztuki — jest jedynie wybiegiem. Z wybiegami tego rodzaju skończył Hegel: duch to rozum historyczny, dziejowy, dokonujący złożonego samorozwinięcia, dla którego postać absolutna, założona przez Kanta jako oczywista, staje się wyłącznie mgliście zarysowującą się paruzją.

Cały wiek XIX pracował na utratę wiary w Kantowską wizję uniwersalnej zasady krytyki, choćby przebierał się przy tym za kantyzm i na samego Kanta powoływał. Kongenialnie względem Kanta Johann G. Herder odkrywa przecież różnicującą moc języka i kultury jako jedynie dostępnych form istnienia ducha; wierzy jeszcze w uniwersalność rozumu, ale zna już tylko jego przygodne historyczne formy. Co by się stało, gdyby odkrył to także Kant? Potwórzmy pytanie Ernesta Gellnera: jak wyglądałby kantyzm, gdyby Kant miał pojęcie kultury? Wilhelm von Humboldt odkrywa zależność postaci rozumu od leksyki oraz struktur gramatycznych i syntaktycznych konkretnych języków, otwierając drogę dla Ludwiga Wittgensteina i tak zwanego przełomu językowego. Marks, mocno dekla-

${ }^{1}$ I. Kant, Uzasadnienie metafizyki moralności, przeł. M. Wartenberg, Warszawa 1984, s. 62. 
rujący się po stronie myśli krytycznej, jednocześnie interpretuje rozum jako formę świadomości uwarunkowaną stosunkami ekonomicznymi oraz społecznymi stosunkami produkcji. Wreszcie Fryderyk Nietzsche w koncepcji perspektywizmu gatunkowego odkrywa w rozumie narzędzie adaptacji ewolucyjnej konkretnego gatunku zwierzęcego, a w metafizyce rozumu — hipostazy właściwości języka, które opisze dokładnie w eseju O prawdzie i fałszu w sensie pozamoralnym.

Myśl dziewiętnastowieczna zatem, myśl, która, w sensie filozoficznym, otwiera naszą współczesność i która nie straciła dla nas aktualności, niewiele pozostawia z Kantowskiej wiary w rozum. Rozum okazuje się hipostazowaną wewnętrzną logiką przygodnych języków, elementem ewolucyjnego przystosowania człowieka, uwarunkowanym przez nasze relacje ze środowiskiem, ideologią absolutyzującą pozycje w walce klas, konstruktem historycznie zmiennym, którego Heglowska paruzja niknie powoli z horyzontu rozważań, okazuje się też posiadać płeć, co do czego przynajmniej Bachofen nie ma już wątpliwości. Ujmując rzecz jak najkrócej: rozum już nie warunkuje, lecz sam jest warunkowany. Nie może już być źródłem czegokolwiek, ponieważ sam ma domagające się wyjaśnienia źródło. Rozum okazuje się pewną postacią kultury, a ta jego forma, którą Kant uważał za uniwersalną, nie ma żadnej innej niż etnocentryczna przewagi. W wieku XX, mimo usiłowań neokantystów i Edmunda Husserla, rozum rozpłynie się w grze kultur i języków, w sieci zewnętrznych uwarunkowań, w układach stylów racjonalności, jak nazwie je Peter Winch, i alternatywnych logik, przybierze postać „transwersalną”, wedle wyrażenia Wolfganga Welscha, czy też ,polimityczną”, jak nazwie to Marquard.

\section{Paradoksy krytyki pozbawionej podstawy}

Owo rozpłynięcie się samej instancji krytyki postawiło myśl krytyczną w kłopotliwej sytuacji, choć nie wszystkie konsekwencje były widoczne od razu. Adorno i Horkheimer zinterpretowali ów moment jako krytyczny punkt procesu, który opisywali pod nazwą dialektyki oświecenia. Oto rozum dokonuje demityzacji samego siebie, to znaczy rozpoznaje pojęcie samego siebie jako mit, który w imię konsekwencji procesu demityzacji nie może zostać spod obowiązku demityzacji wyjęty. Demityzacja rozumu okazuje się przede wszystkim anihilacją jego mocy aksjologicznej, a więc tego aspektu, który wedle Kanta i tak ograniczony już był do praktycznego tylko użycia rozumu. Zdemityzowany rozum staje się ,rozumem instrumentalnym", czyli taką formą rozumu, która jest władna określać racjonalne sposoby realizacji określonych wartości, wykorzystując cały aparat myślowy tradycji krytycznej, ale zwątpiwszy we własną moc aksjologiczną, okazuje się niezdolny nie tylko do wyłaniania, ale nawet do krytycznego przeglądu samych wartości. Nie ma bowiem neutralnego i nieuwarunkowanego punktu wyjścia, a każda aksjologia roszcząca sobie pretensje do racjonalnej w sensie substancjalnym może zostać z powodzeniem oskarżona o to, że absolutyzuje pewien układ 
wartości o przygodnym i historyczno-przypadkowym charakterze. To paraliżujące oskarżenie i niemożność jego odparcia stoi u podstaw niemoty i niemocy rozumu, który staje się aksjologicznie neutralnym zbiorem procedur, odpowiedzialnych już tylko za skuteczność własnych decyzji instrumentalnych. Tę właśnie sytuację wyraża sławne frankfurckie oskarżenie racjonalności o irracjonalność: rozum stał się metodą znajdowania racjonalnych metod realizacji irracjonalnie ustanawianych wartości. Paradoksalnie więc wewnętrzna dynamika myśli krytycznej prowadzi do restytucji ,mitu” już nie w dokładnym rozumieniu etnologicznym, lecz w poszerzeniu, jako każdej legitymizującej narracji ustanowionej poza zasięgiem aksjologicznej mocy rozumu. Sytuacja ta miałaby być społecznie obligatoryjna: bez względu na nasz własny światopogląd w sferze publicznej dominować by miały „mity” czy też lepiej światopoglądy ustanowione poza sferą rozumu, a społeczeństwa — tak zwane społeczeństwa zachodnie — nie miałyby już dopuszczać innych niż tylko instrumentalne sposoby użycia rozumu.

Takiej wykładni historii myśli krytycznej i jej wewnętrznej dynamiki, a zwłaszcza jej frankfurckiej interpretacji jako „dialektyki oświecenia”, można postawić oczywiście wiele zarzutów. Najważniejsze z nich miałyby przy tym zapewne nie charakter filozoficzny, ale wywodziłyby się z kręgu teorii społeczeństwa i teorii kultury. Wydobądźmy trzy takie zarzuty.

Po pierwsze, jeśli dialektyka oświecenia miałaby opisywać strukturę, w której możliwe stały się takie „restytucje mitu” jak nazizm i bolszewizm, to wydaje się za nią stać dość naiwna wizja determinacji przemian społeczno-kulturowych przez przemiany w sferze ideologicznej. Nie trzeba przy tym być konsekwentnym marksistą czy też zwolennikiem jakiejkolwiek innej wersji materializmu kulturowego, aby zgodzić się, że koncepcja tego rodzaju jednokierunkowej determinacji jest niemożliwa do przyjęcia i podpada pod wszystkie zarzuty, jakie sformułowano przeciw nazbyt jednostronnym koncepcjom z zakresu antropologii kognitywnej. Trzeba - jak Hegel - mieć cały system, w którym historia świata daje się interpretować jako rozwinięcie, alienacja i urzeczowienie myślenia, aby móc utrzymywać tego rodzaju wizję. Dialektyka oświecenia, pozostając w swej istocie nie marksizmem, lecz heglizmem, znajduje się w sytuacji paradoksalnej, wymaga bowiem jako podstawy tego rodzaju formy rozumu, której dekompozycję sama głosi.

Po drugie, można pytać, jak dalece przemiany wewnątrz skrajnie elitarnej społecznie formy aktywności - myśli filozoficznej - determinują powszechnie obowiązujące sposoby myślenia lub nawet w jakim stopniu i czy w ogóle są dla niej reprezentatywne. Czy teologia Pseudo-Dionizego Areopagity reprezentuje podstawę pobożności niepiśmiennego Syryjczyka z V wieku albo tradycja intelektualna oksfordzkich franciszkanów - pobożność angielskich chłopów późnego średniowiecza? Może tak, może nie - relacja między kulturą popularną a kulturą elitarną jest bardzo złożona, u frankfurtczyków jednak, poza koncepcją Kulturindustrie, nie została poddana refleksji. Sprawa jest nie tylko teoretyczna, lecz także polityczna. Retorycznie rozbuchany demokratyzm tej koncepcji okazu- 
je się bowiem jedynie deklaratywny, podczas gdy Adorno i Horkheimer a priori zakładają, że wszystkie decyzje kulturowe zapadają na poziomie skrajnie elitarnym i to, co właściwie już nawet zabawne, w kręgu elit intelektualnych, a nie gospodarczych, finansowych, politycznych czy militarnych.

Po trzecie, pozostają kwestie historyczne: jeśli współczesne społeczeństwa „zachodnie” dokonały restytucji „mitu” i kierują się irracjonalnymi wartościami realizowanymi jedynie w racjonalny sposób, to gdzie należy szukać owych szczęśliwych dawniejszych społeczeństw, które realizowałyby aksjologiczną moc rozumu? Miałaby to być owa bajeczna Grecja filozofów (oraz helotów, niewolników, brutalnego militaryzmu Sparty i bezwzględnej ekspansji Aten, niekończących się wojen domowych i bezlitosnej kastowości)? Racjonalnie ustanowiona republika amerykańska, prawdziwy związek wolnych i racjonalnych jednostek (posiadających tysiące, jeśli nie miliony czarnoskórych niewolników, prowadzących planowe ludobójstwo rdzennej ludności)? Niełatwo znaleźć kandydatów. Dialektykę oświecenia można było napisać jako historię myśli, ale nie jako historię społeczeństw. Nagłe przejście w książce Adorno i Horkheimera od jednej płaszczyzny do drugiej niełatwo uzasadnić, tym bardziej że pozostaje ono ukryte i nigdzie niezadeklarowane.

Zarzuty tego rodzaju można mnożyć, ale sprowadzają się one do kłopotów z nazbyt bezpośrednim wykorzystaniem frankfurckiej koncepcji do wyjaśniania przemian w, rzekłby sam Adorno, „społecznej całości”. Zarzuty te nie podważają jednak wagi Dialektyki oświecenia dla zrozumienia sytuacji samej myśli krytycznej; jest to kwestia zasięgu ważności.

Zanim pozwolimy sobie zapytać o ową współczesną sytuację „krytyki kultury” i „humanistyki krytycznej”, podsumujmy krótko poczyniony wywód. Twierdzimy zatem, że:

1. Ustanowienie „humanistyki krytycznej”, oczywiście bez tej nazwy, należy do samego ustanowienia europejskiej tradycji intelektualnej. Pierwszą formą tego rodzaju myślenia była grecka krytyka doksa i dążenie do ustanowienia episteme.

2. Krytyka doksa nie stanowiła podstawy dla znacznie późniejszego odróżnienia nauk formalnych, przyrodniczych i humanistycznych, przeciwstawiając episteme ogólnemu światu mniemań. Przodka humanistyki można poszukiwać $\mathrm{w}$ greckiej krytyce mitu.

3. Ustanowienie wiedzy krytycznej jest zarazem ustanowieniem logosu jako instancji krytyki, w wymiarze zarówno epistemologicznym, jak i aksjologicznym (dla Greków i filozofii chrześcijańskiej — także ontologicznym).

4. Zarówno krytyka grecka w formie sceptycyzmu i sofistyki, jak i myśl nowoczesna od angielskiego oświecenia począwszy, kierują namysł krytyczny ku samej instancji krytyki; proces ten znajduje spełnienie w filozofii krytycznej Kanta jako metodycznego badania zakresów prawomocnego użycia rozumu.

5. Kontynuacja krytyki rozumu prowadzi ostatecznie - wraz ze sprowokowanym przez kolonializm odnowionym doświadczeniem różnicy między ludz- 
kimi sposobami życia - do odkrycia kultury i rozpoznania absolutyzowanego dotąd rozumu jak przygodnego, historycznego wytworu określonego społeczeństwa, uzależnionego od struktur języka, warunków materialnych itp. Odkrycie to w konsekwencji podważa przynajmniej aksjologiczną moc rozumu.

Aby zrozumieć współczesną sytuację myśli krytycznej, trzeba uwzględnić zwłaszcza konsekwencje punktu piątego tego podsumowania. Rozpoznanie zawarte $\mathrm{w}$ tym punkcie należy przy tym uważać za obligatoryjne w tym sensie, że jego skutki nie mogą zostać odsunięte przez żadną formę świadomego archaizmu, to znaczy próbę pominięcia określonych etapów historii myśli krytycznej i restytucji form uprzednich. Nazwijmy rzeczy po imieniu: bez względu na czyjkolwiek światopoglądowy — i w kryteriach światopoglądowych zrozumiały i usprawiedliwiony — protest, każda podstawa krytyki musi wytrwać w obliczu krytyki kantowskiej oraz krytyki antropologicznej. Odkrycie względności kulturowej jest pod tym względem równie zobowiązujące. Kłopoty poznawcze relatywizmu kulturowego - wrócimy do nich jeszcze na chwilę — nie unieważniają samego odkrycia. Wyklucza to właściwie wszelkie formy tradycyjnej podstawy metafizycznej oraz wymusza przekształcenie zasadniczego pytania. Jeśli bowiem rozum jako instancja krytyki jest zawsze, najprościej mówiąc, wytworem pewnej kultury, to należy pytać przede wszystkim o podstawę samej kultury.

Nie ma potrzeby dokonywać tutaj dokładnego historycznego przeglądu proponowanych odpowiedzi na to pytanie, wystarczy zaznaczyć, że większość tych odpowiedzi nie ostała się². Tradycyjna teoria rasowa, dominująca do początku XX wieku, oraz wiele z jej narzędzi, takich jak antropometria, nie przetrwały krytyki zarówno funkcjonalistycznej, jak i krytyki wychodzącej od Franza Boasa, Alfreda L. Kroebera i ich uczniów. Dla przykładu wymieńmy tylko empiryczne badania Kroebera nad zmiennością cech antropometrycznych w jednolitej etnicznie populacji. Podobnie nie utrzymała się koncepcja poligenezy Homo sapiens, leżąca u podstaw wielu postaci teorii rasowej. Inna odpowiedź tradycyjna, w postaci antropologicznego ewolucjonizmu, mimo wysiłków Lesliego White'a sprowokowała, jak wiadomo, własną porcję problemów, począwszy od nieakceptowalnego przemieszania pojęcia ewolucji jako adaptacji środowiskowej i pojęcia postępu oraz łatwy do wykazania właściwie jawny etnocentryzm proponowanych schematów i periodyzacji ewolucji kulturowej. Chociaż ewolucjonizm w teorii kultury pozostaje jak najbardziej możliwy do wyobrażenia, to jednak każda próba jego ustanowienia musi liczyć się ze zniechęcającym dziedzictwem pierwszej próby w tym zakresie. Tradycyjna teoria dyfuzjonistyczna nie tylko popadła w paradoksy wynikające $\mathrm{z}$ dogmatycznego traktowania własnych założeń, widoczne na przykład w badaniu „dyfuzji” egipskiej formy piramidy na terenie Mezoameryki, ale też nigdy nie potrafiła przekonująco i samodzielnie wyjaśnić innowacji kulturowej. Potrzebny był w tej kwestii albo

2 Dla bardzo dokładnego przeglądu krytycznych dyskusji nad koncepcjami źródeł kultury zob. M. Harris, The Rise of Anthropological Theory: A History of Theories of Culture, Altamira 2001.

Prace Kulturoznawcze 23, 2019, nr 1

(C) for this edition by CNS 
rekurs do teorii innego rodzaju, najczęściej ewolucjonistycznej, albo wprost, jak w dyfuzjonistycznej koncepcji Wilhelma Schmidta, do boskiej interwencji. W dyskusji pozostają właściwie cztery opcje: jakaś nowa forma ewolucjonizmu, która uniknęłaby kłopotów teorii tradycyjnej i poradziła sobie z towarzyszącym jej odium; funkcjonalizm, który został mimo poprzednich krytyk odnowiony obecnie w przemyślanej postaci, na przykład w formie socjologicznego neofunkcjonalizmu Jeffreya C. Alexandra; hipoteza neurofizjologicznych źródeł kultury, począwszy od strukturalistycznego jej sformułowania przez Lévi-Straussa; materializm kulturowy w najszerszym rozumieniu. Nie ma powodu, by poddawać teraz dyskusji ewentualne mocne i słabe strony poszczególnych koncepcji i ich wariantów, wybierać którąś z nich i przedstawiać racje wyboru; ważniejsze jest to, że nawet rozwiązanie kwestii źródeł kultury niekoniecznie rozwiązałoby kwestię instancji krytyki.

Podobnie nie rozwiązałoby jej rozstrzygnięcie kwestii relatywizmu kulturowego. Zasadniczy problem relatywizmu wydaje się leżeć w sprzeczności między oczywistym obserwacyjnym potwierdzeniem jego tez a zachodzącym bez wątpienia przezwyciężaniem opisywanej przezeń sytuacji na poziomie prakseologicznym. Gdyby do takiego przezwyciężania nie dochodziło, nie byłyby możliwe żadne procesy międzykulturowe. Jeśli dochodzi do wojny między na przykład Brytyjczykami a Zulusami, to takie proste zdarzenie jak choćby unik zuluskiego wojownika przed ciosem brytyjskiego bagnetu nie mogłoby zajść, gdyby na poziomie prakseologicznym nie istniały dla nich wspólne ponadkulturowe przestrzeń i czas. Dlaczegóż jednak nawet rozstrzygnięcie tych kwestii nie rozwiązałoby problemu uzasadnienia instancji krytyki?

Problem tkwi w tym, co tradycja filozoficzna zna pod nazwą (kantowskiego) dualizmu powinności i bytu — kantowskiego w nawiasie, gdyż chociaż problem należy do sedna Krytyki praktycznego rozumu, to znany był już, jak wspomnieliśmy, Kartezjuszowi i Hume’owi. Ma on wymiar logiczny oraz aksjologiczny.

Od strony logicznej sprawa sprowadza się do niemożności skonstruowania takiego sylogizmu, którego przesłanki są zdaniami opisowymi, a wniosek zdaniem normatywnym. W konstrukcji sylogizmu, którego wniosek jest zdaniem normatywnym, przesłanka większa musi mieć zawsze sama charakter zdania normatywnego, w przeciwnym bowiem razie nie zajdzie między przesłankami a wnioskiem relacja wynikania. Weźmy dla przykładu taki oto sylogizm: przesłanka większa: należy czynić to, co czynia wszyscy ludzie, przesłanka mniejsza: wszyscy ludzie kłamia, wniosek: należy kłamać. Sylogizm ten, który na pierwszy rzut oka mógłby uchodzić za prawidłowe wyprowadzenie zdania normatywnego ze zdania opisowego (przesłanka mniejsza), gdyż zachodzi w nim prawidłowo relacja wynikania, zachowuje swą moc jedynie dzięki temu, że jego przesłanka większa sama jest zdaniem normatywnym. Wewnątrz owego sylogizmu norma zawarta w przesłance większej nie ma uzasadnienia, a więc sama musiałaby być — aby uzasadnienie takie zyskać — wnioskiem innego sylogizmu. Gdyby taki inny sylogizm zbudować, to, pod groźbą non sequitur, musiałby on również mieć zdanie normatywne jako przesłankę więk- 
szą. Wymagałby zatem kolejnego sylogizmu jako własnego uzasadnienia itp. Zatem próba wyprowadzenia porządku normatywnego z porządku opisowego prowadziłaby zawsze nieuchronnie albo do regressus ad infinitum, albo - gdyby proces ów przerwać - do petitio principii, albo — gdyby chcieć uniknąć tych dwóch błędów i odpowiednio połączyć sylogizmy - do curriculum vitiosus. Zatem pod względem logicznym sprawa jest właściwie rozstrzygnięta i jakąkolwiek uzasadnioną racjonalnie aksjologię można by wyprowadzić z empirycznie istniejących układów wartości jedynie na mocy logicznego cudu. Sformułujmy to inaczej, mówiąc, że myśl krytyczna nie może zaakceptować uogólnienia norm jakiejkolwiek kultury, także tej kultury, która wytworzyła sam krytyczny rozum, jako wystarczająco uzasadnionej. Wartości muszą przyjść spoza porządku empirii.

W tym ostatnim stwierdzeniu widoczny już jest drugi wymiar naszego problemu. Otóż empiryczne przestrzeganie bądź nieprzestrzeganie określonej normy przez jakąkolwiek ludzką wspólnotę nie ma żadnego znaczenia dla etycznej słuszności bądź niesłuszności samej tej normy. Gdyby nawet wszyscy ludzie zabijali i gdyby godzili się jawnie lub pokrętnie na to, że zabijać wolno, to nie miałoby to żadnego znaczenia dla etycznej słuszności zakazu „nie zabijaj”. To, co robią inni, choćby i wszyscy inni, nigdy nie usprawiedliwia tego, co robię ja sam. Wyraźmy to językiem Kanta: byt nie określa powinności. Jeśli zatem wartości nie mogą przyjść z porządku empirii, to skąd przyjść mogą? Przyjść mogą z boskiego nakazu, z mocy substancjalnego rozumu, z ejdetycznego oglądu tego, co słuszne. Problem tkwi w tym, że żadna z tych dróg nie ostała się pod spojrzeniem myśli krytycznej. Na tym właśnie polega sedno opisywanej przez frankfurtczyków autodestrukcji oświecenia: nie zostało już żadne miejsce, z którego mogłyby przyjść wartości, a wartości skądś przyjść muszą, gdyż człowiek póki żyje - działa. Jeśli rozum okazuje się pod tym względem bezwładny, coś innego przejmie jego funkcje. O to właśnie chodzi w osławionej „restytucji ślepego mitu". Połączenie odkrycia dualizmu powinności i bytu oraz krytyczna destrukcja źródeł wartości dopiero łącznie owocują zablokowaniem krytycznego myślenia i niemocą rozumu, który rzeczywiście już tylko jako rozum instrumentalny zachowuje wiarygodność. Połączenie to jednak definiuje współczesną sytuację myśli krytycznej w odniesieniu do całej sfery aksjologicznej.

\section{Afiliacja i autonomia krytyki}

Czy sytuacja ta jest nieprzezwyciężalna? Zarówno Marks, jak i Nietzsche ${ }^{3}$ byli przekonani, że wybrnęli z tego paradoksu i że zdołali znaleźć czy ustanowić taką formę myślenia, w której oddzielenie powinności i bytu przestało obowiązywać. Na inne sposoby określili oni byt jako jedyne i prawomocne źródło wartości, wartości

3 Dla szczegółowej dyskusji tego problemu u Marksa zob. L. Kołakowski, Główne nurty marksizmu, Warszawa 2009. Dla kwestii źródeł wartości u Nietzschego zob. G. Deleuze, Nietzsche i filozofia, przeł. B. Banasiak, Warszawa 2012.

Prace Kulturoznawcze 23, 2019, nr 1

(C) for this edition by CNS 
w dodatku konfliktowych, a zadanie myśli krytycznej jako identyfikację wartości słusznych, jako zajęcie stanowiska i wzięcie strony w konflikcie. W tym przekonaniu niemieckich filozofów tkwi dziwny paradoks. Obydwaj myśliciele, których wydaje się tyle dzielić, a których w słusznej intuicji tak ściśle łączył Paul Ricoeur, zgadzają się, że rozum krytyczny nie jest źródłem wartości. Źródłem tym jest proces historyczny i walka klas dla Marksa oraz biologicznie pojęte życie dla Nietzschego. Niech tak będzie, ale czyż i tutaj nie wkrada się petitio principii? Marks chce, byśmy mocą myśli krytycznej rozpoznali, której klasy społecznej świadomość realizuje w danym momencie historycznym postęp rozumiany jako emancypacja, i wzięli stronę tej świadomości. W jego własnej sytuacji była to, jak twierdził, świadomość proletariatu. Nietzsche chce, byśmy rozpoznali autentyczne wartości, jakie generuje samo biologiczne życie, i w ich imię wystąpili przeciw temu, co on sam nazywa „nihilizmem”: zespołom wartości, które przeczą życiu. Osobiście jestem po stronie emancypacji i po stronie życia, ale są to decyzje uprzednie względem przedstawionych przez filozofów rozumowań. Aby zaufać Marksowi, aby solidaryzować się z tą siłą historyczną, która przynosi wolność, muszę najpierw uznać wartość samej wolności. Aby zawierzyć Nietzschemu, muszę najpierw przyjąć wartość samego życia. Ostatecznie więc to, co oni opisują, to wejście w konflikt, w którym nie mamy racji dla swoich wartości, a jedynie przeciwstawiamy się wartościom nam przeciwnym: tym ludziom, którzy twierdzą, że przynoszące zysk zniewolenie jest lepsze niż emancypacja, że zaprzeczenie życiu jest lepsze niż jego afirmacja. Poza tym, że musimy z sobą walczyć, jaka inna racja niż nasze własne przekonanie może stać za ostatecznie nieuzasadnionym etycznym wyborem? Może Marks i Nietzsche mają rację, może jest to kwestia nieuzasadnialnego wyboru, ale nieuzasadnione jest także twierdzenie, że paradoks powinności i bytu został w ich myśli rozwiązany. Został jedynie pominięty i zignorowany, zadeklarowano tylko jego przezwyciężenie. Słownik finalny więc, rzekłby Richard Rorty, wciąż nie ma dostatecznej racji.

Można więc współczesną sytuację myśli krytycznej opisać krótko. W swym wymiarze poznawczym, demaskatorskim, jako demistyfikacja doksa, jest ona niezagrożona. Jako pozytywny proces ustanawiania wartości jest pozbawiona podstaw i sparaliżowana. Możliwe są dwa wyjścia. Pierwsze starał się opisać Adorno w Dialektyce negatywnej, postulując taką formę rozumu krytycznego, który nie ma już żadnej postaci pozytywnego projektu, a jedynie negatywną moc samej krytyki. Sytuuje się, by ując sprawę po heglowsku, zawsze po stronie heterogenicznej antytezy, nigdy nie przechodząc do żadnego Aufhebung, nie zawierając w sobie żadnej obietnicy. Taki czysto negatywny rozum jest w konstrukcji społeczeństwa i myśli Goetheańskim „duchem, który wiecznie przeczy”. Jest to wyjście konsekwentne, ale zapewne nierealizowalne. Kłopotliwe pytania można postawić samej Adornowskiej Dialektyce negatywnej: duch wiecznie przeczy, ale w imię czego przeczy? Dlaczego podważa to, co podważa? W co wierzy (jak najbardziej pozytywnie), skoro stara się odnaleźć i podważyć (jak najbardziej negatywnie) każdy moment panowania i przemocy? Nie trzeba wielkiej przenikliwości, by za 
dialektyką negatywną, mimo wszelkich wysiłków Adorna, odkryć jednoznaczny i pozytywnie określony aksjologiczny kościec, który dopiero funduje negatywność rozumu i który zresztą dopiero powoduje, że negatywność ta nabiera istotności, nie stając się tylko „grą szklanych paciorków”. Projekt Adorna nie znalazł wielu kontynuatorów. Przychodzi na myśl jedynie Derrida i jego dekonstrukcja jako wieczne odsuwanie metafizyki i niemożność ukonstytuowania się metafizycznej myśli, ale przecież już nie jego literaturoznawczy naśladowcy, pozbawieni filozoficznej wrażliwości swojego mistrza, którzy pozwolili dekonstrukcji z owego „odwlekania” i „różnicowania” przekształcić się w metodę i metafizykę na opak.

Drugą możliwością myśli krytycznej, wskazaną już przez Marksa i Nietzschego, jest afiliacja względem systemów wartości przychodzących spoza sfery krytycznego rozumu. Humanistyka lewicowa i prawicowa, feministyczna i katolicka, mają bowiem tyle przynajmniej z sobą wspólnego, że dokonują właśnie afiliacji względem wielkich społecznych ruchów emancypacyjnych, nacjonalistycznych czy jakichkolwiek innych, których aksjologię przyjmują za własną, utożsamiają się z nią i wyłączają z zasięgu krytyki. Przedmiotem krytyki jest jedynie aksjologia przeciwna. Ostatecznie jest to jednak nieuświadomiony pyrronizm, wygrywanie jednych doksa przeciw innym doksa, bez troski o źródło wartości i jego krytykę, a jedynie ze względu na siłę własnego przekonania. Decyzje aksjologiczne pozostają jednak uprzednie względem aktu krytycznego. Z jednymi spośród tych aksjologii będziemy się solidaryzować, inne, co oczywiste, wywołają nasz sprzeciw, co pozwoli nam przeoczyć, jak bardzo podobny jest ich status. Ostatecznie bowiem chodzi o oddanie się we władzę zewnętrznym siłom społecznym, o - by się tak wyrazić - zewnątrzsterowność humanistyki krytycznej, a więc humanistyki w ogóle, o dobrowolne oddanie się w służbę sympatycznego lub nierestytuowanego „mitu”. Tak oto, zgodnie z prognozą frankfurtczyków, racjonalność staje się irracjonalna, przekształcając się jedynie w projekcję społecznego konfliktu. Trzeba to jednak wyrazić precyzyjnie: rozpoznanie to nie oskarżenie, zapewne trzeba w ów konflikt się włączać, tyle że czynimy to dla racji ustanowionych poza zasięgiem krytyki, choć naiwnie lub nieuczciwie przedstawiamy owe racje jako efekt krytycznego namysłu, a nie aksjologie wyrażające naszą pozycję i sposób uczestniczenia w społecznym życiu.

Zewnątrzsterowność myśli krytycznej i jej afiliacyjny charakter można by uznać za poddanie się rozumu i radosną afirmację jego niemocy. Niemoc ta została już społecznie rozpoznana, czego efektem są zmiany w społecznym statusie humanistyki. Humanista - czy wzorem tu może być na przykład publiczny charakter postaci takich jak Jean-Paul Sartre — od którego jeszcze niedawno oczekiwano wzięcia na siebie roli sumienia społeczeństwa i głosu krytycznej myśli pośrodku chaosu konfliktów, przekształcony został w dostarczyciela wiedzy eksperckiej potrzebnej do realizacji programów, których aksjologia została określona gdzie indziej. Dzisiejszy humanista to rodząca się nowa postać rozumu instrumentalnego, potrzebny w tej postaci rzeczywistym decydentom. Właściwy namysł krytyczny stracił istotność i przekształca się na naszych oczach w rodzaj przemysłu humanistyki, konkuren- 
cji, w której krytyczny namysł służy do negocjowania własnej pozycji na rynku wytworów humanistycznych lub wewnątrz samocelowego systemu nauki. Logika ta widoczna jest zwłaszcza w historii wszelkich „zwrotów”, jakie dokonywały się ostatnio w humanistyce: każdy z nich łączy przecież nierozerwalnie rzeczywisty wymiar krytyczny — każdy rodził się jako odpowiedź na rzeczywiste poznawcze i aksjologiczne wyzwanie - i każdy zarazem był taktyczną zagrywką w polu naukowej autopromocji. Raz jeszcze jest to rozpoznanie, a nie oskarżenie. Wspomniana zewnąrzsterowność humanistyki, a raczej nauki w ogóle, uwidoczniła się najpełniej w nowej organizacji życia naukowego, w jakiej ocena pracy naukowej przestała mieć związek z jakąkolwiek wagą dokonania, a jedynie mierzy relację owego dokonania względem czysto formalnego systemu oceny, odcinającego naukę zarówno od całości życia społecznego, jak i od tak sławionego rynku, gdyż ostatecznie system ten jest zamkniętym kołem konkurencji o pieniądze publiczne. Jeszcze jeden paradoks współczesnej sytuacji myśli krytycznej: aksjologiczna afiliacja do wielkich sił społecznych, która mogłaby przynajmniej nadać na nowo humanistyce publiczną doniosłość, odbywa się wewnątrz zautonomizowanego i samoreferencyjnego systemu nauki, który zamyka tę humanistykę w odizolowanym kręgu cyrkulacji. W sytuacji tej wewnętrzny kryzys podstaw myśli krytycznej i zewnętrzne przedefiniowanie reguł społecznej gry zbiegły się w fatalny sposób.

Czy z tego błędnego koła można wyjść? Nie wiadomo, ale początkiem mogłoby być dążenie do odzyskania autonomii - myślowej, a nie formalnej i systemowej — krytycznego rozumu, do odzyskania jego mocy aksjologicznej, a więc przeciwstawienie mocy empirii innego źródła wartości, które wytrzymuje samą krytykę. Jakiego? Brakuje tutaj odpowiedzi, ale jeśli w tym wywodzie mam choć odrobinę racji, to empiryczna trudność, a choćby i niemożliwość jego odnalezienia, nie ma wpływu na moc etycznego obowiązku jego poszukiwania. Być może trzeba by nawet zrobić tak, jak chciał Martin Heidegger — wrócić przed Sokratesa i sofistów i zacząć na nowo?

\section{Criticism as the dynamics of humanistic thought}

\section{Abstract}

The text is dedicated to the reconstruction of the idea of the philosophical critique of culture. The emphasis is being put on the origins of such criticism in the Greek distinction between doxa and episteme and its developement through the philosophical criticism of the myth. Next comes the problem of the extension of philosophical critique to the very conditions of the possibility of knowledge, achieved by Immanuel Kant, and the effects of this extension for the status of reason. This leads to the concept of the instrumentalization of reason and opens a possibility of consideration of the contemporary status of philosophical criticism.

Keywords: culture, critique, reason, knowledge

Prace Kulturoznawcze 23, 2019, nr 1

(C) for this edition by CNS 


\section{Bibliografia}

Deleuze G., Nietzsche i filozofia, przeł. B. Banasiak, Warszawa 2012.

Harris M., The Rise of Anthropological Theory: A History of Theories of Culture, Altamira 2001.

Kant I., Uzasadnienie metafizyki moralności, przeł. M. Wartenberg, Warszawa 1984.

Kołakowski L., Główne nurty marksizmu, Warszawa 2009.

Prace Kulturoznawcze 23, 2019, nr 1

(C) for this edition by CNS 